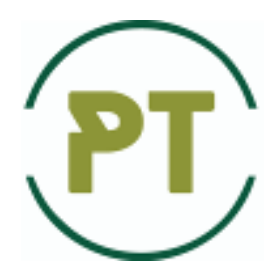

\title{
Substantiation of informative amplitudes during registration of acoustic emission signals from the friction zone of tribosystems
}

\author{
V.A. Vojtov, K.A. Fenenko, A.V Voitov \\ Kharkiv Petro Vasylenko National Technical University of Agriculture, Kharkiv, Ukraine \\ E-mail:vavoitovva@gmail.com
}

\begin{abstract}
In this work, the dependence of the change in the probability density of the distribution of the number of pulses and amplitudes of acoustic emission (AE) signals from the friction zone at the steady-state operation of the tribosystem is obtained. Acoustic vibrations that the tribosystem generates during operation are due to the impact interaction of the roughness of the friction surfaces of their elastoplastic deformation, processes of formation and destruction of frictional links, structural and phase rearrangement of materials, the formation and development of microcracks in the surface layers of contacting bodies, separation of wear particles. The dependence allows you to determine a sufficient number of pulses in the signal frame and their amplitude values for diagnosing tribosystems during their operation. The values of the informative amplitudes of the clusters are experimentally substantiated $K 2, K 3, K 4$ in relation to the base cluster $K 1$. It is shown that an increase in the informative frequency $f_{A E(f i x)}$ from 250 to $500 \mathrm{kHz}$, increases the value of the informative amplitude to $17,6 \ldots 43,75 \%$. Based on the results obtained, it was concluded that this fact must be taken into account when developing methods, which will increase the accuracy of diagnosing tribosystems.

The autocorrelation coefficient characterizes the closeness of the linear relationship of the current and previous frames of the series for each of the analyzed clusters. By the value of the autocorrelation coefficient, one can judge the presence of a linear relationship between the values of the recorded amplitudes, their reproducibility in terms of recording time in the steady-state operation of the tribosystem.

To confirm the sufficiency of the selected number of pulses in the clusters of the AE signal frame, as well as the reproducibility of the results of the analysis of frames when they shift in time of registration, an expression is obtained for calculating the autocorrelation function, which reflects the relationship between successive levels of the time series. Based on the results of the experimental data, the values of the autocorrelation coefficients were calculated, equal to $0,82 \ldots 0,92$, which indicates the robustness of the chosen diagnostic technique.
\end{abstract}

Key words: tribosystem; probability density; acoustic emission; cluster analysis; informative frequency; informative amplitude; autocorrelation function.

\section{Introduction}

The first publications on the application of acoustic emission (AE) as a method for diagnosing friction units, emerged in the late 1970 s as a way to monitor friction and wear processes online. With the modern development of means for recording signals, the use of this method makes it possible to obtain information on the state of friction surfaces in the online mode.

Acoustic vibrations that the tribosystem generates during operation are due to the impact interaction of the roughness of the friction surfaces of their elastoplastic deformation, processes of formation and destruction of frictional links (mode stick-sleep [1]), structural and phase rearrangement of materials, the formation and development of microcracks in the surface layers of contacting bodies, separation of wear particles.

Currently, acoustic emission is actually understood as a secondary process, which is a superposition of signals from a huge number of elementary AE sources, i.e. acoustic radiation is a consequence of the collective processes of structural units (material structural defects). Moreover, it is believed that this secondary process is the result of the interference of primary acoustic waves that satisfy the coherence condition. 


\section{Literature review}

In works [2, 3] analysis of publications on the use of AE for diagnosing various tribosystems, where it is concluded that studies on acoustic emission diagnostics of mechanisms are based on the use of discrete emission features. As for continuous emission, it is characterized by the parameters - root-mean-square deviation, crest factor, vibration spectrum [4]. In addition, time parameters are used (duration of the rise and fall of the pulses) [4], parameters of pulse amplitude distribution and wavelet transform [5].

Based on the analysis of works [6-11], in work [12] it is concluded that a promising direction is the substantiation of acoustic emission signs of defects invariant to signal amplitude scaling. This is due to the fact that signal fluctuations, differences in the amplitude-frequency characteristics of the sensors, affect the measurement result of energy parameters of emission, such as energy, average value of amplitudes, spectrum and result of wavelet transform.

The work is devoted to the selection of informative AE parameters for diagnostics of tribosystems [13], where it was theoretically and experimentally established that informative frequencies depend on the following groups of factors: constructive; technological and operational. The degree of influence of the listed factors on the change in the frequency range is determined. Operating factors (sliding speed and load) change the frequency range from 106 to $584 \mathrm{kHz}$, technological factors (roughness of friction surfaces) change the frequency range from 118 to $618 \mathrm{kHz}$, design factors (the value of the friction area of a fixed triboelement) change the frequency range from 140 to $530 \mathrm{kHz}$. It is concluded that for effective diagnostics of tribosystems, it is necessary to first determine the informative frequency range, taking into account the above factors.

To justify the choice of informative AE parameters in the work [14] a cluster analysis of AE signal frames from the friction zone of the tribosystem was performed with the division of the signal into groups of sources of its generation. A correlation has been established between the wear rate, the coefficient of friction and the values of the peak factor of various clusters. It has been experimentally confirmed that the cluster analysis of acoustic emission signals from the friction zone of the tribosystem allows identifying surface processes during wear, thereby increasing the robustness and information content of the AE method. The authors conclude that this analysis can serve as the basis for the development of a technique for diagnosing tribosystems during their operation, which will allow you to measure the wear rate at any time and calculate the tribosystem resource.

Based on the performed analysis of the work, it can be concluded that to determine the wear rate and the coefficient of friction during the operation of tribosystems (in the online mode), it is necessary to preliminarily determine the informative frequency range and within the boundaries of this range perform separation of the $\mathrm{AE}$ signal into components - clusters. Analysis of each cluster will provide information on a separate group of processes occurring in the surface layers of tribosystem materials, which will increase the robustness of this method and the information content of diagnostics.

\section{Purpose}

The purpose of this study is to substantiate informative amplitudes when registering AE signals from the friction zone of tribosystems taking into account the values of informative frequencies.

\section{Methods}

Based on the formulas given in the work $[13,14]$, let us simulate the distribution of the number of pulses in the general packet of $\mathrm{AE}$ signals from the friction zone over clusters $K 2-K 4$. Experimental studies with the registration of frames for the tribosystem: steel $40 \mathrm{H}$ (movable triboelement) + Br.AZh 9-4 (fixed triboelement) at various loads, allows plotting the dependence of the probability density of the distribution of the number of AE pulses from the friction zone over the amplitudes. During the experiment, frames of length $t=1 * 10^{-3} \mathrm{~s}$. For the above tribosystem on loads $N=500 \ldots 1500 \mathrm{~N}$ band of informative frequencies for a fixed triboelement Br.AZh 9-4 is in the range $f_{A E(f i x)}=250 \ldots .500 \mathrm{kHz}$, this follows from the expression given in the work [14]:

$$
f_{A E(f i x)}=n \cdot \dot{\varepsilon}_{f i x} \cdot\left(1+\mu_{f i x}\right) \cdot\left(1-2 \mu_{f i x}\right) \text {. }
$$

where $f_{A E(f i x)}$ - information frequency of AE signals from the friction zone, dimension $1 / \mathrm{s}$;

$n$ is the the total number of contact spots on the friction surface of a fixed triboelement is determined by the formulas given in the work [14];

$\dot{\varepsilon}_{f i x}$ is the value of the deformation rate of the material of a fixed triboelement at a single spot of actual contact, dimension $1 / \mathrm{s}$, is determined by the formulas that are given in the work [14];

$\mu_{f i x}$ is the Poisson's ratio of the material of the fixed triboelement. 


\section{Results}

The dependences of the probability density of the distribution of pulses and amplitudes in the AE signal frame are plotted for the steady-state operating modes of the tribosystem in the boundary lubrication mode, fig. 1. Curves that characterize clusters $K 1, K 2, K 3, K 4$, obtained experimentally. The probability density of the registered impulses of individual clusters $N_{K i}$ we define in relation to the total number of pulses of the base cluster.

The envelope curve of the probability density of the distribution of pulses and amplitudes in the $\mathrm{AE}$ signal frame, curve 1, is approximated by the expression:

$$
\frac{N_{K i}}{N_{\Sigma}}=\frac{N_{K 1}}{N_{\Sigma}} \cdot \exp \left(-\frac{A_{K i}}{A_{K 1}}\right)
$$

where $N_{K i}$ is the the number of pulses that the i-th cluster contains;

$N_{\Sigma}$ is the total number of pulses in the cluster;

$N_{K l}$ is the the number of pulses that the 1 st cluster contains $K 1$;

$A_{K i}$ is the the magnitude of the amplitudes belonging to the $\mathrm{i}$-th cluster;

$A_{K l}$ is the the magnitude of the amplitudes belonging to the cluster $K l$.

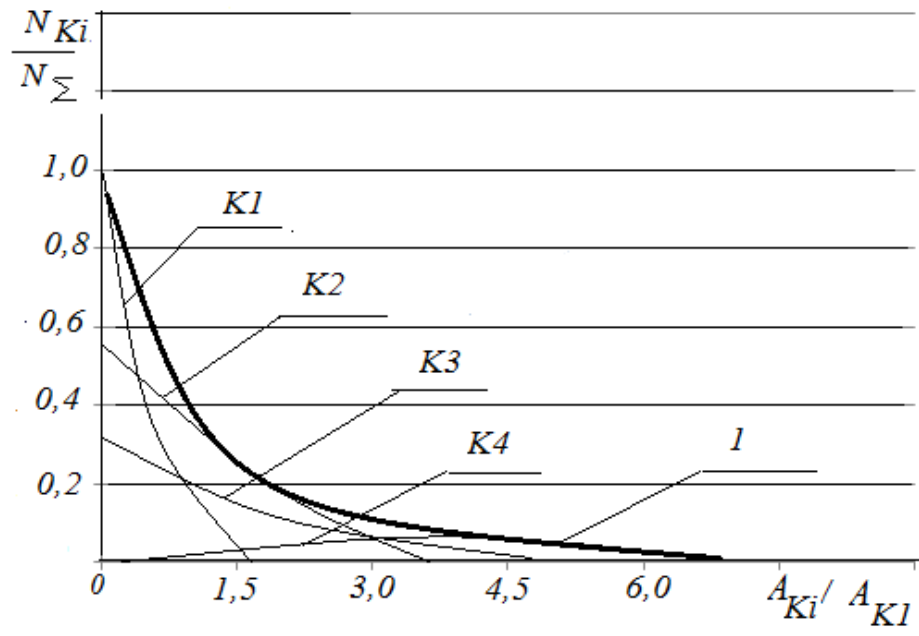

Fig.1. Dependences of the change in the probability density of the distribution of pulses and amplitudes in the steady-state operation of the tribosystem under $\operatorname{load} N=1500 \mathrm{~N}: 1$ - envelope curve

By progression of expression (2) we obtain:

$$
\ln \frac{N_{K i}}{N_{\Sigma}}=\ln \frac{N_{K 1}}{N_{\Sigma}}+\left(-\frac{A_{K i}}{A_{K 1}}\right) .
$$

Assuming that the number of pulses in the frame $N_{\Sigma}$ is equal to the number of pulses in the base cluster $K 1$, expression (3) takes the form:

$$
\frac{A_{K i}}{A_{K 1}}=-\ln \frac{N_{K i}}{N_{\Sigma}}
$$

The simulation results according to expression (4) make it possible to establish the value of the ratio of amplitudes $A_{K i} / A_{K l}$ to perform diagnostics tribosystems. The resulting value of the amplitude $A_{K i}$ is called the informative amplitude that characterizes the i-th cluster.

For example, for tribosystem designs, where the informative frequency band corresponds $f_{A E(f i x)}=250$ $\mathrm{kHz}$, the total number of informative pulses during the signal registration time equal to $t=1 * 10^{-3} \mathrm{~s}$, will be $N_{\Sigma}=$ 250 impulses. In the course of the experiment, at this informative frequency, the magnitudes of the amplitudes were recorded, which, based on the work [13] characterize clusters $K 2, K 3, K 4$. The results of calculation by formula (4) make it possible to determine the excess of informative amplitudes relative to the base cluster $K 1$.

The magnitudes of the ratio of the amplitudes are:

- for cluster $K 2$ :

$$
\frac{A_{K 2}}{A_{K 1}}=-\ln \frac{50}{250}=1,6
$$

- for cluster $K 3$ : 


$$
\frac{A_{K 3}}{A_{K 1}}=-\ln \frac{20}{250}=2,52
$$

- for cluster $K 4$ :

$$
\frac{A_{K 4}}{A_{K 1}}=-\ln \frac{5}{250}=3,91
$$

Pulse count values for a cluster $K 2$, equal to 50 pulses; cluster $K 3$, equal to 20 pulses; cluster $K 4$, equal to 5 pulses, obtained experimentally.

For tribosystem designs, where the informative frequency band corresponds $f_{A E(f i x)}=500 \mathrm{kHz}$, the total number of informative pulses during the signal registration time equal to $t=1 * 10^{-3} \mathrm{~s}$, will be $N_{\Sigma}=500$ impulses.

The values of the excess of informative amplitudes relative to the base cluster $K 1$ make up:

- for cluster $K 2$ :

$$
\frac{A_{K 2}}{A_{K 1}}=-\ln \frac{50}{500}=2,3
$$

- for cluster $K 3$ :

$$
\frac{A_{K 3}}{A_{K 1}}=-\ln \frac{20}{500}=3,21
$$

- for cluster $K 4$ :

$$
\frac{A_{K 4}}{A_{K 1}}=-\ln \frac{5}{500}=4,6
$$

The obtained values of the excess of the informative amplitudes of the clusters $K 2, K 3, K 4$ relative to the base cluster $K 1$, allow you to clarify the data given in the work [13] and draw a conclusion about the dependence of the informative amplitudes $A_{K i}$ from informative frequency $f_{A E(f i x)}$. As follows from the formulas (5) - (10) increase of informative frequency $f_{A E(f i x)}$ from 250 to $500 \mathrm{kHz}$, increases the value of the informative amplitude by $17,6 \ldots 43,75 \%$. This fact must be taken into account when developing methods, which will increase the accuracy of diagnosing tribosystems.

To confirm the sufficiency of the selected number of pulses $N_{K i}$ a certain amplitude $A_{K i}$ in the clusters of the AE signal frame, as well as the reproducibility of the results of the analysis of the frames when they are shifted in registration time, we will use the autocorrelation function, which reflects the connection between successive levels of the time series.

The autocorrelation function can be quantitatively determined using the linear correlation coefficient between the levels of the original frame of the AE signal amplitudes $A_{t}$ and the levels of this series, shifted by several steps in time $A_{t-\tau}$.

Autocorrelation coefficient of time series levels $r_{A}$, measuring the relationship between adjacent levels of a series $A_{t}$ and $A_{t-\tau}$, calculated by the formula:

$$
\begin{aligned}
r_{A} & =\frac{\sum_{i=1}^{N}\left(A_{t}-\bar{A}_{t}\right) \cdot\left(A_{t-\tau}-\bar{A}_{t-\tau}\right)}{\sqrt{\sum_{i=1}^{N}\left(A_{t}-\bar{A}_{t}\right)^{2} \cdot \sum_{i=1}^{N}\left(A_{t-\tau}-\bar{A}_{t-\tau}\right)^{2}}}, \\
\text { where } \bar{A}_{t}=\frac{\sum_{i=1}^{N} A_{t}}{N-1} ; \quad \bar{A}_{t-\tau} & =\frac{\sum_{i=1}^{N} A_{t-\tau}}{N-1} .
\end{aligned}
$$

Similarly, the autocorrelation coefficients of the second, third and fourth clusters of AE signal frames shifted in time are determined by the formula: 


$$
\begin{gathered}
r_{A, K i}=\frac{\sum_{i=1}^{N}\left(A_{t, K i}-\bar{A}_{t, K i}\right) \cdot\left(A_{t-\tau, K i}-\bar{A}_{t-\tau, K i}\right)}{\sqrt{\sum_{i=1}^{N}\left(A_{t, K i}-\bar{A}_{t, K i}\right)^{2} \cdot \sum_{i=1}^{N}\left(A_{t-\tau, K i}-\bar{A}_{t-\tau, K i}\right)^{2}}}, \\
\text { where } \bar{A}_{t, K i}=\frac{\sum_{i=1}^{N} A_{t, K i}}{N-1} ; \quad \bar{A}_{t-\tau, K i}=\frac{\sum_{i=1}^{N} A_{t-\tau, K i}}{N-1} .
\end{gathered}
$$

Based on experimental data, according to the formula (12), autocorrelation coefficients were calculated $r_{A, K i}$. For the amplitudes that characterize the cluster $K 2$, the autocorrelation coefficient is 0,92 ; for cluster amplitudes $K 3$, the autocorrelation coefficient is 0,88 ; for cluster $K 4$, the autocorrelation coefficient is 0,82 .

The autocorrelation coefficient characterizes the closeness of the linear relationship of the current and previous frames of the series for each of the analyzed clusters. By the value of the autocorrelation coefficient, one can judge the presence of a linear relationship between the values of the recorded amplitudes, their reproducibility in terms of recording time in the steady-state operation of the tribosystem. High values of autocorrelation coefficients, equal to $0,82 \ldots 0,92$, indicate the robustness of the selected tribosystem diagnostics technique in the process of operation.

Based on the findings of previous work [13] let us formulate the physical meaning of the processes on the friction surface of tribosystems, which are characteristic of the following clusters.

Signal source generating a cluster $K 2$ are: jumps in deformation on the spots of actual contact, as a result of which slip bands are formed; abrupt movement of the roughness ridges due to changes in the adhesion forces, which in operation [1] named as mode stick-sleep.

Signal source generating a cluster $K 3$ are: formation of fatigue cracks parallel and perpendicular to the friction surface; separation of wear particles from the friction surface in the form of flakes or petals by the mechanism of fatigue wear; separation of wear particles from the friction surface by the mechanism of "rolling" of oxide films or secondary structures.

Signal source generating a cluster $K 4$ are: microcutting and plastic creasing of the protrusions of the friction surface roughness, which is characteristic of the first stages of running in.

\section{Conclusions}

The dependence of the change in the probability density of the distribution of the number of pulses and amplitudes of acoustic emission signals from the friction zone at the steady-state operating mode of the tribosystem has been established. The dependence allows you to determine a sufficient number of pulses in the signal frame and their amplitude values for diagnosing tribosystems during their operation. The values of the informative amplitudes of the clusters are experimentally substantiated $K 2, K 3, K 4$ relative to the base cluster $K 1$. It is shown that an increase in the informative frequency $f_{A E(f i x)}$ from 250 to $500 \mathrm{kHz}$, increases the value of the informative amplitude by $17,6 \ldots 43,75 \%$. This fact must be taken into account when developing methods, which will increase the accuracy of diagnosing tribosystems.

To confirm the sufficiency of the selected number of pulses in the clusters of the AE signal frame, as well as the reproducibility of the results of the analysis of frames when they shift in time of registration, an expression for calculating the autocorrelation function is obtained, which reflects the relationship between successive levels of the time series with autocorrelation coefficients equal to $0,82 \ldots 0,92$, which indicates the robustness of the chosen diagnostic technique.

\section{References}

1. Ferrer C., Salas F., Pascal M., Orozco J. Descrete acoustic emission waves during stick-slip friction between steel samples, Tribology International, 2010, No.43, pp.1-6. [English]

2. Shevchenka S.A. Klasyfikatsiya ta obgruntuvannya vymoh do akustyko-emisiynykh oznak defektiv par tertya mekhanizmiv, Visnyk Kharkivs'koho natsional'noho tekhnichnoho universytetu sil's'koho hospodar-stva im.P.Vasylenka, 2012, vyp.121, s.159-163. [Ukraine]

3. Abdullah M., D. Al-Ghamd, Zhechkov, D. Mba. A comparative experimental study on the use of Acoustic Emission and vibration analysis for bearing defect identification and estimation of defect size, Mechanical System and Signal Processing, 2006, No.7, pp.1537-1571. [English]

4. Mazal P., V.Koula, F.Hort, F.Vlasic. Applications of continuous sampling of AE signal for detection of fatigue damage, NDT in Progress, 2009, No.4. -8 p. [English]

5. Yanhui Feng. Discrete wavelet-based thresholding study on acoustic emission signals to detect bearing defect on a rotating machine, The Thirteen International Congress of Sound and Vibration. Vienna, Austria, 2-6 
July, 2006. -8 p. [English]

6. Faris Elasha., Matthew Greaves, David Mba, Abdulmajid Addali. Application of Acoustic Emission in Diagnostic of Bearing Faults within a Helicopter gearbox, The Fourth International Conference on Through-life Engineering Services. Procedia CIRP, 2015, Vol.38, pp. 30-36. [English]

7. Seyed A. Niknam, Tomcy Thomas, J. Wesley Hines, Rapinder Sawhney. Analysis of Acoustic Emission Data for Bearings subject to Unbalance, International Journal of Prognostics and Health Management, 2013, Vol. 15, pp. 1-10. [English]

8. Badgujar M.P., Patil A.V. Fault Diagnosis of Roller Bearing Using Acoustic Emission Technique and Fuzzy Logic, International Journal of Latest Trends in Engineering and Technology, 2014, Vol. 3, Issue 4, pp.170-175. [English]

9. Rao V.V., Ratnam Ch. A Comparative Experimental Study on Identification of Defect Severity in Rolling Element Bearings using Acoustic Emission and Vibration Analysis, Tribology in Industry, 2015 , Vol. 37, No. 2, pp.176-185. [English]

10. Zahari Taha., Indro Pranoto. Acoustic Emission - Research and Applications. Chapter 4 - Acoustic Emission Application for Monitoring Bearing Defects, InTech. 2013, pp.71-90. http://dx.doi.org/10.5772/55434 [English]

11. Nienhaus K., Boos F.D., Garate K., Baltes R. Development of Acoustic Emission (AE) based defect parameters for slow rotating roller bearings, Journal of Physics: Conference Series. 364. 2012. 012034. 1-10. doi:10.1088/1742-6596/364/1/012034 [English]

12. Yongyong He., Xinming Zhang, Michael I. Friswell. Defect Diagnosis for Rolling Element Bearings Using Acoustic Emission, Journal of Vibration and Acoustics, 2009, Vol. 131 / 061012. [English]

13. Fenenko K.A. Cluster analysis of acoustic emission signals from the friction zone of tribosystems / Problems of Tribology, V. 25, No 2/96-2020, 25-33 DOI: https://doi.org/10.31891/2079-1372-2020-96-2-25-33 [English]

14. Fenenko K.A. The determination of the information frequencies in the frame of the acoustic emission signals from the friction zone of tribosystems / Problems of Tribology, V. 25, No 3/97-2020, 6-13 DOI: https://doi.org/10.31891/2079-1372-2020-97-3-6-13 [English] 
Войтов В.А., Фененко К.А., Войтов А.В. Обгрунтування інформативних амплітуд при реєстрації сигналів акустичної емісії із зони тертя трибосистем

В роботі представлені результати дослідження щодо обгрунтування інформативних амплітуд при реєстрації сигналів акустичної емісії (AЕ) із зони тертя трибосистем з урахуванням значень інформативних частот.

Отримано залежність зміни щільності ймовірності розподілу кількості імпульсів і амплітуд сигналів акустичної емісії з зони тертя на сталому режимі роботи трибосистеми. Залежність дозволяє визначити достатню кількість імпульсів в фреймі сигналів, а також величини амплітуд для діагностування трибосистем в процесі їх експлуатації. Експериментально обгрунтовані значення величин інформативних амплітуд кластерів $K 2, K 3, K 4$ щодо базового кластера $K 1$. Показано, що збільшення інформативної частоти $f_{A E(H)} 3250$ до 500 кГц, збільшує значення інформативної амплітуди на $17,6 \ldots$ 43,75\%. На підставі отриманих результатів зроблено висновок, що даний факт необхідно враховувати при розробці методик, що підвищує точність діагностування трибосистем.

Для підтвердження достатньості вибраної кількості імпульсів в кластерах фрейма сигналів AE, а також відтворюваності результатів аналізу фреймів при зсуві їх за часом регістрації, отримано вираз для розрахунку автокореляційної функції, яка відображає зв'язок між послідовними рівнями тимчасового ряду. За результатами експериментальних даних розраховані значення коефіцієнтів автокореляції, які дорівнюють 0,82 ... 0,92, що свідчить про робастність обраної методики діагностування.

Ключові слова: трибосистеми; щільність ймовірності; акустична емісія; кластерний аналіз; інформативна частота; інформативна амплітуда; автокореляційна функція. 